\title{
Self protection and stop bullying campaign for kids at RPTRA Sungai Bambu, Tanjung Priok, Jakarta Utara
}

\section{Suraya Mansur}

Mercu Buana University, Indonesia, suraya.suraya@mercubuana.ac.id

Follow this and additional works at: https://scholarhub.ui.ac.id/ajce

Part of the Gender, Race, Sexuality, and Ethnicity in Communication Commons

\section{Recommended Citation}

Mansur, Suraya (2020). Self protection and stop bullying campaign for kids at RPTRA Sungai Bambu, Tanjung Priok, Jakarta Utara. ASEAN Journal of Community Engagement, 4(1).

Available at: https://doi.org/10.7454/ajce.v4i1.1075

Creative Commons License

(c) (i) ()

This work is licensed under a Creative Commons Attribution-Share Alike 4.0 License.

This Research Article is brought to you for free and open access by the Universitas Indonesia at ASEAN Journal of Community Engagement. It has been accepted for inclusion in ASEAN Journal of Community Engagement. 


\title{
Self-protection and "Stop Bullying" campaign for kids at Child- friendly Integrated Public Space Sungai Bambu, Tanjung Priok, Jakarta Utara
}

\author{
Suraya Mansura*

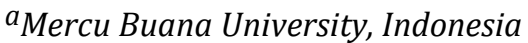 \\ Received: March $8^{\text {th }}, 2020||$ Revised: March $24^{\text {th }}$, May $5^{\text {th }}, \&$ July $26^{\text {th }}, 2020||$ Accepted: July $2^{\text {th }}, 2020$
}

\begin{abstract}
This paper presents a socialization and counseling program anchored on the themes "selfprotection" and "stop bullying." The program aims to explain the importance of knowing what parts of our body can and cannot be touched by other people, the need to be vigilant when invited to quiet places either by known or unknown people, and how to act in such situations. Bullying is sometimes undetected because it is considered normal or funny. Therefore, children must be told that calling names in the form of ridicule or hitting others is an unjustified action. The methods used in this program are socialization and counseling. The program, which was attended by 50 children, was implemented in the Sungai Bambu Child-friendly Integrated Public Space (RPTRA) Tanjung Priok, North Jakarta on Saturday, December 01, 2018. The children sang "Sentuhan Boleh Sentuhan Tidak Boleh." (What You Can Touch and What You Can't Touch) together with their peers. Results show that children who participate in community service activities exhibit an increased level of knowledge and awareness of self-protection by following the instructions in the song.
\end{abstract}

Keywords: counseling; self-protection; simulation; socialization; stop bullying; traditional game.

\section{Introduction}

Sexual harassment and sexual violence are serious issues. Ironically, most victims are children. The commissioner of KPAI (Commission for Children's Protection in Indonesia) stated that 218, 180, and 116 cases of child sexual abuse were reported in 2015, 2016, and 2017, respectively. These numbers show how alarming this issue is in Indonesia. KPAI found that most of the perpetrators are the victims' close relatives (Setyawan \& KPAI, 2017).

Retno reports that majority of the cases occurred at the elementary school level. Of the 37 cases in January-April 2019, 25 occurred in elementary school, whereas the lowest number of cases (i.e., 1) was reported in the college level (Maradewa, 2019). The following data (Table 1) on cases of child sexual violence (from 2011 to 2018) were provided by KPAI (Jabar Tribun News, 2019)

\footnotetext{
*Correspondence Author: suraya.suraya@mercubuana.ac.id
} 
Suraya Mansur | ASEAN Journal of Community Engagement | Volume 4, Number 1, 2020

Table 1. Cases of Child Sexual Violence

\begin{tabular}{ccc}
\hline No. & Years & Cases \\
\hline 1. & 2011 & 2178 \\
2. & 2012 & 3412 \\
3. & 2013 & 4311 \\
4. & 2014 & 5066 \\
5. & 2015 & 4309 \\
6. & 2016 & 4622 \\
7. & 2017 & 4579 \\
8. & 2018 & 4885 \\
\hline
\end{tabular}

Children cannot spot sexual predators, especially when such predators could be anyone they know or anyone they interact with every day; it could be their parents, relatives, neighbors, or even their favorite teacher. Most of the people in Indonesia have been told from early age to be careful when interacting with strangers, that is, to refuse to go with them or scream if they force us to go. The fact that underaged children are seen as sexual objects leaves us heartbroken (Morrison et al., 2018).

Zhang et al. (2014) stated three factors could lead to child sexual abuse: (1) sexual attraction to prepubescent children (i.e., pedophilia), (2) exposure to pornographic media, and (3) children's lack of sexual education. Based on these factors, sexual abuse should be treated as an extraordinary crime in which victims need immediate and comprehensive care. All sectors, including parents, the government, and KPAI, of the community must participate and cooperate to protect minors from sexual violence.

Most minors that are prone to sexual abuse live in densely populated areas, where residents live too close to each other. Consequently, crime rates in such areas are high. The government has reminded that all citizens must be vigilant to safeguard children. Sexual violence includes but is not limited to molestation and rape; such violence affects children psychologically and leads to an unstable mental condition. If not treated properly, then repercussions, such as lack of life spirit, hate for the opposite sex, and tendency to revenge, last for a lifetime (Morrison et al., 2018).

All children have the right to feel safe, comfortable, and happy. The amended Law of the Republic of Indonesia on Child Protection (Setiawan et al., 2019) states that every 
child has the right to be protected and educated; this law should be implemented without discrimination of race, religion, class, gender, ethnicity, culture and language, legal status, birth order, and physical and/or mental capabilities (Setyawan \& KPAI, 2017).

Children have the right to security, comfort, pleasure, and excitement. The Law of the Republic of Indonesia concerning Child Protection (UU Number 35, 2014) has stated that children must receive protection, which includes all activities to guarantee and protect children and their rights so that they can live, grow, develop, and participate optimally in accordance with human dignity and obtain protection from violence and discrimination. This law further reinforces that an individual child is protected by the state from all kinds of actions that interfere with his life and development. Thus, if a child experiences an act of violence, then the state participates in handling it.

Bullying is another familiar word even if it has never been translated into Bahasa Indonesia. Even violence is not enough to represent bullying itself. Bullying leaves huge scars and trauma on its victims (Hong \& Espelage, 2012).

As a tribute to Indonesia's National Child Day 2018, KPAI released a disclosure regarding child sexual abuse cases in the year 2018. Nine divisions concerning child abuse have released their data in the year 2018 (Setyawan, 2018; Widiastuti, 2018; KPAI, 2020). The commissioner of KPAI Child Education Division believes that victims can be classified into five categories, namely, victims of brawls between schools/gangs, participants of brawls between schools/gangs, victims of child violence and bullying, initiator of child violence and bullying, and victims of policies (illegal levies, expulsion from school, exclusion from exams, and dropouts) (Rostanti, 2015).

Bullying is not limited to physical abuse, such as hitting, grabbing, slapping, or coercion to give money. It can also come in the form of verbal abuse, such as cursing, mocking, gossiping, and psychological abuse, which includes intimidation, seclusion, and discrimination. All of these kinds of abuse may happen at a young age. Most parents shrug off these red flags under the mask of jokes. Victims of bullying experience high levels of stress and have low self-esteem; in addition, victims can possibly become a bully themselves (Hong \& Espelage, 2012; Laurensius, Situngkir, Putri, \& Fauzi, 2019; Limawan, Wiguna, Ismail, \& Sekartini, 2016).

Bullying cases are common. In Indonesia, 8 of 10 citizens are victims of bullying in real life and in the cyber world. Bullies have three types: the main actor, the followers, and third actor or the passive actor. The main actors exercise power play and initiate physical 
Suraya Mansur | ASEAN Journal of Community Engagement | Volume 4, Number 1, 2020

and/or psychological violence. By contrast, the followers or secondary actors bully other people to show their solidarity with or gain recognition from others. As for the third actor or the passive actor, fall into bystander effect with almost zero will to help the victim (Hong \& Espelage, 2012; Laurensius, Situngkir, Putri, \& Fauzi, 2019).

Jakarta is a densely populated area with uncoordinated slums and thus tends to have a high level of crime rate, especially those involving women and children. Therefore, a safe and comfortable space must be created for its residents. In addition, a safe green area where kids can play is needed because of the dangerously high number of roads and highways. The Integrated Child-friendly Public Space (Ruang Publik Terpadu Ramah Anak, RPTRA) of Sungai Bambu is located under a highway linking Cawang and Tanjung Priok, Jakarta. This space used to be a housing area; unfortunately, it was demolished due to the construction of the highway. (Fajarta, 2017).

Survey shows that RPTRA Sungai Bambu operated as a hangout for the mothers and a playground for their kids from morning to sundown. The researcher had a meeting with Ms. Leni Herawati, the head coordinator of RPTRA, and she explained the regular activities being held on RPTRA Sungai Bambu. A survey was conducted on one weekend, as kids gathered and Ms. Leni played a song titled "Sentuhan Boleh Sentuhan Tidak Boleh" (What You Can Touch and What You Can't Touch). She explained that the song has been played repeatedly, but she did not know the meaning of the song.

This community service aims to develop children's self-awareness and self-protection to prevent child maltreatment in the RPTRA Sungai Bambu Tanjung Priok area. Child maltreatment can be initiated by children as well. The main goal of this community service is for children to understand the importance of the song "Sentuhan Boleh Sentuhan Tidak Boleh" (What You Can Touch and What You Can't Touch); which they hear almost every day, and the extent of bullying that they probably do to others unconsciously.

This program is expected to educate and raise children's awareness about bullying. Survey shows that children who listen to "Sentuhan Boleh Sentuhan Tidak Boleh" (What You Can Touch and What You Can't Touch) while playing around the RPTRA Sungai Bambu Tanjung Priok area without their mother's or sister's supervision perceive the true meaning of the song. However, the appointed guardians do not respond when kids hit each other, steal each other's toys, or call other names. 
This survey shows that the kids of RPTRA Sungai Bambu receive education through a song without exerting any effort to understand its meaning. However, kids accept bullying as a normal occurrence because guardians show less to no response to child maltreatment. Therefore, understanding the meaning of "Sentuhan Boleh Sentuhan Tidak Boleh" (What You Can Touch and What You Can't Touch), accompanied by countermeasures when meeting strangers or being touched inappropriately by someone else, is important for kids to recognize bullying behavior.

Public relations campaigns hold two meanings: in a narrow sense and in a broad sense. In a narrow sense, the campaign aims to raise awareness and educate the target audience to foster positive perception or opinion toward corporate activities and gain trust and good image using intense message delivery through a continuous communication process (Rice \& Atkin, 2017). In a broad sense, the campaign aims to provide continuous understanding to motivate the community toward a particular activity or program through processed communication techniques and plan to achieve publicity and positive image (Suraya, 2019).

Socialization is an effort to convert an individual's property into a people's property (state property) or a learning process as a member of society to recognize and live the culture in their environment. From the children's perspective, socialization is a linking process that allows them to learn social values so they can become mature and responsible citizens (Parke et al., 2008; Parsons et al., 2014). According to Herskovits, socialization is a process by which a child adjusts to the norms in his family (Kemenkes RI, 2013).

Individuals can achieve four objectives during socialization (Ashforth et al., 2007): (1) Socialization can help individuals achieve their identity physically and mentally. (2) Socialization helps each individual or group to develop their humanistic potential and learn how to live in the society. (3) Socialization meets basic human needs to survive in the society. (4) Socialization helps individuals or groups to imitate their respective culture.

Socialization can be divided into two types: (1) primary socialization, which is a process that occurs since childhood, and (2) secondary socialization, which is performed by the individual based on the lessons he/she learned. Primary socialization starts from the family, where the individual begins to learn to distinguish himself from others around him. At this stage, an individual learns for the first time about family culture, religion, and 
Suraya Mansur | ASEAN Journal of Community Engagement | Volume 4, Number 1, 2020

rules. In secondary socialization, a person learns to recognize his environment outside the family and the values and norms, which exist in the community. In general, secondary socialization is a determinant of one's attitude because a person has adapted to various community environments (Laurensius, Situngkir, Putri, \& Fauzi, 2019; Parsons et al., 2014; Wang et al., 2012).

Etymological counseling provides information, explanation, guidance, path, and direction that must be taken by each person to solve the problems he/she faces and improve his/her quality of life (Bor \& Allen, 2014; Gibson \& Cartwright, 2014; Sori \& Hecker, 2015). According to Geldard \& Geldard (2008), counseling is an activity of educating the community by providing information and new abilities so that they can shape new attitudes and behavior (Bor \& Allen, 2014; Vangelisti, 2004).

Counseling is a nonformal educational activity to change society toward an improved condition as desired. In an effort to change the community, elements, such as ideas or concepts taught by institutions, initiate changes in society as a whole to disseminate ideas in question. In addition, the community members individually and as a whole are the targets of counseling activities (Hurlock, 1967).

The philosophy of counseling is to work with the community to help them increase their dignity as humans. On the basis of this opinion, (1) counseling agents must cooperate with the community and not work for the community. The presence of counseling agents is not as a determinant or enforcer, but he must be able to create a dialogical atmosphere with the community and be able to grow, mobilize, and maintain community participation. (2) Counseling does not create dependency but must be able to encourage the creativity and independence of the community; Counseling develops the ability to represent, self-help, and self-manage and then it was implemented into activities that achieve the goals, hopes, and desires of the target community. (3) Counseling must always refer to the achievement of the economic welfare of the community and increase the dignity of its members as a human being (Bor \& Allen, 2014).

Simulation refers to imitation or a pretending act (Shanton \& Goldman, 2010). As a teaching method, simulation can be interpreted as an activity that describes an actual situation. Participants play a role in artificial simulations to describe an actual event. Thus, in simulation activities, participants or role holders imitate an artificial environment of actual events (Tsuda, Scott, Doyle, \& Jones, 2009). 
According to Akselbo, Olufsen, Ingebrigtsen, \& Aune (2019), Supriadi \& Sa'ud (2017) and Nielsen (2002), simulations are a replica or visualization of the behavior of a system, for example, an educational plan, which runs at a certain period. Thus, simulations are a model that contains a set of variables that display the main characteristics of an actual life system. Simulations allow decisions that determine how the main features to be substantially modified.

Simulation methods have two types (Powell et al., 2016): (1) Role playing: In this learning process, game patterns in the form of dramatization are prioritized. Dramatization is implemented by groups of students using a mechanism directed by a teacher to perform predetermined/planned activities. This type of simulation focuses on the purpose of remembering or recreating a picture of the past that is possible in the future or an event that is actual and meaningful at present. (2) Sociodrama: This roleplaying learning method aims to solve problems related to social phenomena and human relationships. It is performed by groups to conduct problem solving that is related to individual problems as social beings, e.g., relationship between children and parents and between students and their friends. (3) Simulation games: In this learning method, students play roles following the roles assigned by students to make decisions.

Child maltreatment can be overcome by conducting sex education to children as early as possible. The activity to educate the children about the importance of sex education was performed by (Tsuda, Scott, Doyle, \& Jones, 2017) in Yogyakarta. regarding the importance of sex education for children in Yogyakarta. Holzner \& Oetomo (2004) also conducted an event on sex education, especially related to youth, sexuality, desire, and control. Research on the importance of education regarding sexual violence among children was also conducted by Norris (2015) and Ellsberg et al. (2015). Since sexual violence could lead to pornography on social media, the impact of social media and the ethics of using it should be included into the sex education (Kholisoh, 2018). A study included community involvement in children's school curricula, involving all stakeholders to conduct community counseling services, including for child sexual violence case (Villaluz, 2017; Morrison et al., 2018), The community could also involve through media campaign prevention program (Self-Brown, Rheingold, Campbell, \& De Arellano, 2008) and sustainability assessment (Dewi, 2017). 


\section{Methods}

This research was conducted using the postpositivistic paradigm and qualitative descriptive approach. The techniques or methods of implementation used in activities on the Sungai Bambu RPTRA include socialization (1 hour), counseling (1 hour), and simulation with singing and traditional games ( 2 hours). Socialization was used to explain the meaning of the song "Sentuhan Boleh Sentuhan Tidak Boleh" (What You Can Touch and What You Can't Touch), which is composed by Sri Seskya Situmorang and sung by Indri Ayu Lestari (Fitrianny, 2017). The goal was for children to understand the meaning of the song. Counseling for "Stop Bullying" aimed to help children identify words or attitudes and actions that are considered bullying. Simulation was conducted to observe whether the children understood the material given.

Neni, the Sungai Bambu RPTRA coordinator, said that the area is guarded by six officers. Records show that RPTRA is visited by at least 100 people every day (children and adults) (Simanjuntak, 2019). A total of 50 children, which comprised the sample, were selected from the population of children in Sungai Bambu RPTRA to participate in the socialization. The key informants of this research were Ms. Leni Herawati (head coordinator of RPTRA) and Ani Wahyu Haryadi (Head of PKK Jakarta Utara). Children who lived around the Sungai Bambu RPTRA participated in the research. The names of the children are as follows: 1 . Yasmin (9 years old), Balqis (10 years old), Bagas (8 years old), and Ijul (10 years old). This research used socialization, simulation, counseling, and observational and analytic methods to describe the implementation of the self-protection and "stop bullying" campaigns for kids. Moreover, the research used narrative analysis by Milles, Huberman, \& Saldana (2014).

The socialization and counseling activities used pre- and post-tests for 50 children in RPTRA Sungai Bambu Jakarta Utara. The questions are shown in Table 2.

Table 2. Questions of Pre- and Post-Test

\begin{tabular}{|c|c|c|}
\hline No & Category & Questions \\
\hline \multirow[t]{2}{*}{1.} & Self-Protection & $\begin{array}{l}\text { 1. Do you know which parts of our body cannot } \\
\text { be touched by others? }\end{array}$ \\
\hline & & $\begin{array}{l}\text { 2. Do you want to be invited to a quiet place by a } \\
\text { stranger? }\end{array}$ \\
\hline
\end{tabular}




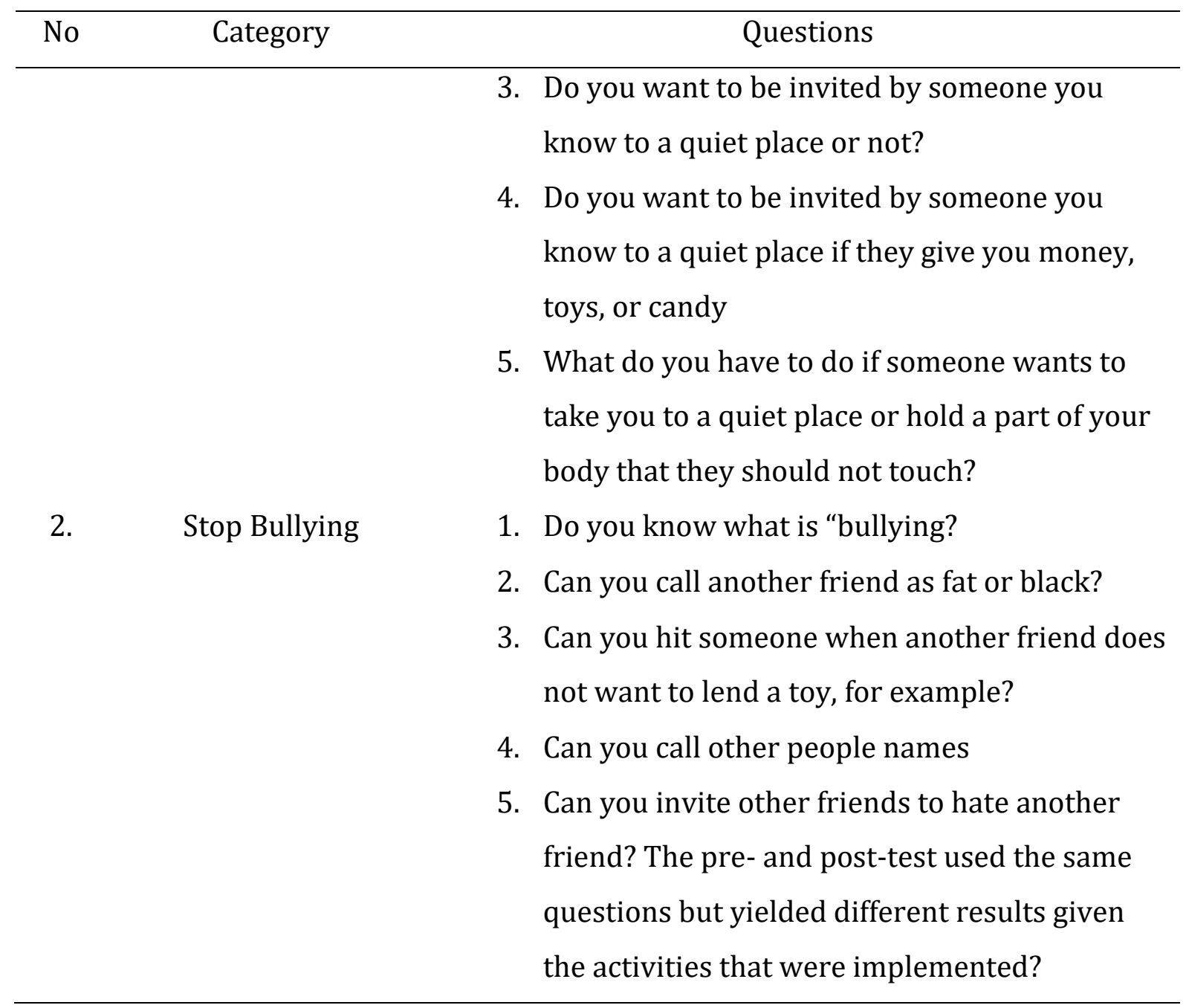

Source: Data processing from Authors (2019)

\section{Result and Discussion}

The Mercu Buana University conducts community engagement activities to raise children's awareness about the importance of security. This activity gives unique advantages because the method of delivery is not limited to one method. Socialization is implemented by using songs accompanied with traditional dances and games, simulations are implemented through role playing, and counseling is provided. Results show that the children learn how to take care of themselves, love each other, and look out for each other. The children have also become aware of the benefit of being united.

The RPTRA is used by residents as a place of commune and a playground for children. Leni Herawati, Head of RPTRA Sungai Bambu Jakarta said that the community used to gather, chat, and play with children around the RPTRA area. Despite the RPTRA being built under the highway, the atmosphere is calm and comfortable. 
Suraya Mansur | ASEAN Journal of Community Engagement | Volume 4, Number 1, 2020

The materials delivered comprised pictures for children to understand them easily. Animated videos were also shown so that children do not feel bored; moreover, delivery is clear and straightforward. Singing along with movements became the highlight of the program because the children are excited to sing "Touch Touch Touch Touch No" with actions.

During the simulation, male and female body parts and which body parts may be touched and not touched by others are explained. Teaching aids that are immediately understood by children were used for the simulation.

The large hall of RPTRA can be used for sitting and lying down, and children can safely use the available playground. "It's a common thing here that there are families who will bring their own mat, foods, then gather until night," she said. The RPTRA area is open to the public, but Leni stressed that those who come to RPTRA should abide by the rules applied in the RPTRA. "Anyone can come here, as long as they follow the regulations. For example, to not smoking, because the RPTRA is a non-smoking area," she said.

The RPTRA also provides activities that hone nonacademic abilities, such as vocal groups, angklung practices, gymnastics, dancing, pencak silat, hadroh, and futsal. The activities take place every Saturday and Sunday, starting at 8 AM. Nongovernmental organizations, local communities, youth and sports organizations, and tourism and culture agencies provide these activities. The children are also reminded about good manners during these activities.

North Jakarta PKK Chairperson Ani Wahyu Haryadi said the existence of the RPTRA is a positive means of playing and interacting with their peers.

"Hopefully this activity can further motivate children from an early age. The existence of the activities in this RPTRA to ensure the lives of citizens are healthier and more quality, is increasingly realized with empowerment activities and positive activities that are routinely carried out every day."

One of the kids (Yasmin (9 years) grade IV, MI AL-Ihsaniyah Tanjung Priok student) said

"I like to play here afterschool, most likely to go to the library, reading fairy tales books, and school textbooks as well, besides, it's cool here. I came to know after the activities with my brothers here that I must not be naughty to other children, and also take care of our bodies so that they are not touched by others."

Meanwhile, Balqis (10 years) said

"there used to be adults, especially motorbike taxi (Ojek) that used to like to poke or touch me. I think it's normal, but it can have negative consequences. I also know how the bodies of boys and girls are and which 
Suraya Mansur | ASEAN Journal of Community Engagement | Volume 4, Number 1, 2020

should not be touched, the teacher thought us the song and dance movements, that was really fun, because the movements can be followed easily so we come to know where our bodies should not be touched by other people. Eventually I became aware of my own body."

Leni Herawati believes that offering activities for free can help parents who lack money for activities outside school. "We both know, the parents of these children are economically deficient. The main priority for them is for their children to be able to attend school, so RPRTA can help to add more knowledge and fun afterschool."

According to Bagas (8 years),

"usually when we play together, we will taunt each other or even push each other, eventually it becomes a fight. Having explained by the teacher here, I finally realized that this would be bad for us. Moreover, we become more united as friends on traditional game session."

"Actually, we are not aware that the danger of sexual violence can also occur in boys. I think it's only happened to girls. The teacher gave me examples of cases and the effects of sexual violence on men, I became scared," said Ijul, who was 10 years old. "Finally, I am now even taking care and looking after the others who are playing in the RPTRA here."

Since the RPRTA was established, the children's character considerably improved.

"There were times where parents will scold their children with awful choice of words, and kids being kids, mimic all of it. But now, we slowly teach them how to behave properly, in method that the kids are comfortable with it," she said.

Leni said that she considers the children around RPTRA as her own children.

"Every time I'm arrived, I was greeted with hug. And there were times where I am so proud of their development," she said.

Based on the descriptions above, efforts are needed to prevent children from experiencing sexual harassment and violence and become bullies or being bullied. Such efforts can be implemented through the self-protection and "stop bullying" socialization program for children. This activity should provide education to children about what should and what should not be done when interacting or playing with peers or older people.

The committee incentivized kids who answered questions with prizes. This strategy was successful because the children become enthusiastic to answer and sing when asked to sing the song. When traditional games were conducted, the children became eager to win because the winner would be given a prize. They were ecstatic, and several children asked to play again so that their team could win prizes. The games played were Keripik Jengkol Gado-Gado Lontong for children aged 10-12 years and Ular Naga Panjangnya for children aged 7-9 years. 
Suraya Mansur | ASEAN Journal of Community Engagement | Volume 4, Number 1, 2020

Gimmick given to RPTRA itself is some traditional children such as, congklak, bekel ball, gundu. Modern games, such as Uno Cards and Monopoly board game, were also played. All the games were chosen with a consideration that it can be played by two or more people.

The first activity is socialization for self-protection. The activity was facilitated by Ms. Maya Afia. The materials used include a PowerPoint presentation, videos, and the song "Sentuhan Boleh Sentuhan Tidak Boleh" (What You Can Touch and What You Can't Touch). The PowerPoint presentation was made simple and used animated images for the children to understand it easily. The video aired was a video made by the Indonesian Child Protection Commission (KPAI) in Denpasar City. As mentioned previously, the song was composed by Sri Seskya Situmorang and sung by Indri Ayu Lestari. The second activity, which was delivered by Ms. Natasha Mirza, was counseling and a simulation of "Stop Bullying."

The "Stop Bullying" video was taken from youtube.com/baboonzchannel because of the images, music background, and simple yet interesting delivery. Anyone who watched it would understand the message easily and interested to watch until the end.

For the simulation activities, the children were grouped into four groups at the beginning of the activity. They began all activities together, starting from registration to sitting together and playing traditional games. The children also did not want to be separated again into another group even though their ages varied. In one simulation, four children called another child "fat." This issue was raised by the facilitator. The four children were asked to apologize directly to the child they called "fat" and promised to start calling their real names from then on. Then, the child they called "fat" was also asked if he would accept the apology. We hope that in the future, these children would not forget their promises, and no other children will follow this behavior again.

Indicators of success tendency can be observed from the results of the pre- and posttest. The results show that the target participants reach a certain level of understanding from the material provided, and the participants are satisfied with the material and the implementation of activities, sponsorship, and media coverage. A total of 50 people comprised the target participants of self-protection and "stop bullying" socialization and counseling.

The post-test was measured through questionnaires, which assessed three aspects: the material provided, the teacher/presenter, and the training methods used. The 
questionnaire is an indicator of success-whether the objectives were achieved in accordance with the expectations and what aspects must be evaluated and learned for future research.

Based on the results of the questionnaire (Table 1) with a Likert scale model, which is commonly used to measure the perceptions, attitudes, or opinions of a person or group regarding an event or social phenomenon, the results are as follows:

Table 3. Pretest Results

\begin{tabular}{|c|c|c|c|}
\hline No. & Questions & Score & Index \\
\hline 1. & $\begin{array}{l}\text { Do you know which parts of our body cannot be touched by } \\
\text { others? }\end{array}$ & 321 & $66.9 \%$ \\
\hline 2. & Do you want to be invited to a quiet place by a stranger? & 319 & $66.5 \%$ \\
\hline 3. & $\begin{array}{l}\text { Do you want to be invited by someone you know to a quiet } \\
\text { place or not? }\end{array}$ & 319 & $66.5 \%$ \\
\hline 4. & $\begin{array}{l}\text { Do you want to be invited by someone you know to a quiet } \\
\text { place if they give you money, toys, or candy }\end{array}$ & 316 & $65.8 \%$ \\
\hline 5. & $\begin{array}{l}\text { What do you have to do if someone wants to take you to a } \\
\text { quiet place or hold a part of your body that they should not } \\
\text { touch? }\end{array}$ & 318 & $66.3 \%$ \\
\hline 6. & Do you know what is "bullying? & 332 & $69.2 \%$ \\
\hline 7. & Can you call another friend as fat or black? & 331 & $69.0 \%$ \\
\hline 8. & $\begin{array}{l}\text { Can you hit someone when another friend does not want to } \\
\text { lend a toy, for example? }\end{array}$ & 316 & $65.8 \%$ \\
\hline 9. & Can you call other people names & 321 & $66.9 \%$ \\
\hline 10. & $\begin{array}{l}\text { Can you invite other friends to hate another friend? The pre- } \\
\text { and post-test used the same questions but yielded different } \\
\text { results given the activities that were implemented? }\end{array}$ & 319 & $66.5 \%$ \\
\hline
\end{tabular}

Source: Data processing from Authors (2019)

Based on the results of the pretest (Table 3), children who participated in the activity said they could distinguish and understand the danger of touch by strangers $(66,9 \%)$. They also said they could recognize people who would behave badly (65\%). The children said that know about bullying and hit someone when another friend bother them (69\%). 
Table 4. Post-Test Results

\begin{tabular}{|c|c|c|c|}
\hline No. & Questions & Score & Index \\
\hline 1 & $\begin{array}{l}\text { Do you know which parts of our body cannot be touched by } \\
\text { others? }\end{array}$ & 421 & $87.7 \%$ \\
\hline 2 & Do you want to be invited to a quiet place by a stranger? & 419 & $87.3 \%$ \\
\hline 3 & $\begin{array}{l}\text { Do you want to be invited by someone you know to a quiet } \\
\text { place or not? }\end{array}$ & 367 & $76.5 \%$ \\
\hline 4 & $\begin{array}{l}\text { Do you want to be invited by someone you know to a quiet } \\
\text { place if they give you money, toys, or candy }\end{array}$ & 416 & $86.7 \%$ \\
\hline 5 & $\begin{array}{l}\text { What do you have to do if someone wants to take you to a } \\
\text { quiet place or hold a part of your body that they should not } \\
\text { touch? }\end{array}$ & 418 & $87.1 \%$ \\
\hline 6 & Do you know what is "bullying? & 426 & $88.8 \%$ \\
\hline 7 & Can you call another friend as fat or black? & 432 & $90 \%$ \\
\hline 8 & $\begin{array}{l}\text { Can you hit someone when another friend does not want to } \\
\text { lend a toy, for example? }\end{array}$ & 431 & $89.8 \%$ \\
\hline 9 & Can you call other people names & 419 & $87.3 \%$ \\
\hline 10 & $\begin{array}{l}\text { Can you invite other friends to hate another friend? The pre- } \\
\text { and post-test used the same questions but yielded different } \\
\text { results given the activities that were implemented? }\end{array}$ & 406 & $84.6 \%$ \\
\hline
\end{tabular}

Source: Data processing from Authors (2019)

To interpret the results, the data on Table 4 was processed using the Index $\%$ formula.

Formula of Index $\%=$ Total Score $/$ Y $x 100$.

Resulting in

$=$ Total Score $/$ Y x 100

$=421 / 480 \times 100$

$=87.7 \%$ Very Good category

The formula for finding the index is the total score of the participants' answers divided by the highest total score times 100 (to get the percentage). If the total score is above $70 \%$ it can be said to be very good. 
The results reveal that $90 \%$ of students stated that "They Know", they do not want to call another friend as fat or black, and $89.8 \%$ of students stated that they do not want to hit someone when another friend does not want to lend a toy, for example. A total of $88.8 \%$ of students stated that they know what "bullying" is.

Almost all children (boys and girls) who participated in this socialization activity realized the importance of protecting themselves and their friends without having to bully each other. Previously, they lacked knowledge about which body parts should not be touched. They even considered it normal when others poke or even touch them on their sensitive parts. The children quickly understood the message because they were able to point out the parts of the body that can and cannot be touched while singing and dancing.

Eighty percent of the self-protection and "stop bullying" material used images and an animated video that supports the explanation of the material. The satisfaction level of the participants can be observed from their enthusiasm when the materials were presented, when questions were being asked, when singing together, and when playing traditional games. The self-protection and "stop bullying" campaign activities have been published on Kompas Muda (muda.kompas.id). The self-protection and "stop bullying" campaign activities have strengths and limitations, as shown on Table 5.

Table 5. Strengths and Limitations of Campaign

\begin{tabular}{lll}
\hline NO & Category & \multicolumn{1}{c}{ Statement } \\
\hline A. Strenghts & 1. & This socialization and counseling activity were \\
& conducted seriously, starting from the preparations \\
& to the day the activity was implemented to achieve \\
& consistency with the expectations of the organizing \\
& committee. \\
2. & The program was supported by Brins General \\
& Insurance in the form of paper bags, agenda, and \\
& pens. \\
3. & This activity was supported in social media, such as \\
Instagram (@ firar.id) and Kompas Muda.
\end{tabular}




\begin{tabular}{l} 
NO Category \\
\hline 4. The activities, including surveys; sponsor searches; \\
purchase of items needed for goodie bags, game \\
prizes, and gimmicks for Sungai Bambu RPTRA, were \\
organized and arranged by the researchers \\
themselves. \\
5. The organizers were positively welcomed by \\
residents of the Sungai Bambu Village, especially by \\
the children who were around the location. \\
6. This activity is a manifestation of the team's love and \\
concern for the nation's future children. \\
1. The research had a limited number of participants \\
(50 children, limited to age 7-12 years). \\
2. Access to the location was somewhat confusing when \\
using an online map guide. Someone who has arrived \\
at the location should share their location coordinate. \\
3. The nature of children can be considered a limitation. \\
Some kids interrupted in the middle of session to go \\
to the toilet \\
4. The concentration of young children is much shorter \\
than adults; thus, when they were taught, their \\
thention must be drawn to the material repeatedly so
\end{tabular}

Source: Data processing from Authors (2019)

These community service activities are similar to research that are cited in this study. The difference between this study and previous ones is the nonpartial method used. The method combines socialization, simulation, and counseling through songs and traditional games. This feature is the novelty of this study.

\section{Conclusion}

Self-protection and "Stop Bullying" campaign activities were conducted, aiming to raise awareness on the importance of knowing which body parts can and cannot be 
touched by others, the need to be vigilant when invited to quiet places either by known or unknown people, and how to act if such a situation happens. Moreover, bullying is not easily recognized because it is considered normal or even funny. Thus, children must be told that calling names to ridicule and hitting are unjustified actions. Socialization and simulation for children to prevent sexual violence and avoid bullying are needed. Children who participated in the activity have their knowledge and awareness of selfprotection improved.

Counseling and "Self-Protection and Stop Bullying" socialization activities were performed as a communication campaign strategy. Communication campaigns aim to raise the awareness and knowledge level of the target audience and shape the audience's perception into a positive mindset within a certain period. In a broad sense, public relations campaigns are conducted to raise community engagement by enlightening issues and motivating the public to aim for self-protection and stop bullying.

Parents or older people need to reprimand children when another child is hit or called names. Children who are mocked must be empowered to defend themselves and refuse to be called as such. The community must be educated about self-protection so that they can protect their children and families and empower children in villages to protect and educate each other.

\section{Author Contribution}

Suraya Mansur is the sole author of this paper. All ideas were conceived and executed by the author.

\section{Acknowledgments}

The researcher would like to thank Prof. Dr. Ngadino Surip as the Chancellor of the Mercu Buana Jakarta University, director of research and community service Universitas Mercu Buana who have provided opportunities, funding and material. special thanks to the A translator from the alumni of English literature UGM Yogya who has helped translate and proofread this article. 


\section{References}

Akselbo, I., Olufsen, V., Ingebrigtsen, O., \& Aune, I. (2019). Simulation as a learning method in public health nurse education. Public Health Nursing, 36, 226-232.

https://doi.org/10.1111/phn.12560

Angka Kekerasan terhadap Anak selama 2018 Meningkat, Ada Pertambahan Sekitar 300 Kasus (2019, January 18). Jabar Tribunnews.

https://jabar.tribunnews.com/2019/01/18/angka-kekerasan-terhadap-anakselama-2018-meningkat-ada-pertambahan-sekitar-300-kasus

Ashforth, B. E., Sluss, D. M., \& Saks, A. M. (2007). Socialization tactics, proactive behavior, and newcomer learning: Integrating socialization models. Journal of Vocational Behavior, 70, 447-462.

https://doi.org/10.1016/j.jvb.2007.02.001

Bor, R., \& Allen, J. (2014). Counselling. In Cambridge Handbook of Psychology, Health and Medicine, Second Edition.

https://doi.org/10.1017/CB09780511543579.076

Dewi, O. C. (2017). Sustainability assessment on community park revitalization. ASEAN Journal of Community Engagement, 1(1), 83-95.

https://doi.org/10.7454/ajce.v1i1.63

Ellsberg, M., Arango, D. J., Morton, M., Gennari, F., Kiplesund, S., Contreras, M., \& Watts, C. (2015). Prevention of violence against women and girls: What does the evidence say? The Lancet, 385, 1555-1566.

https://doi.org/10.1016/S0140-6736(14)61703-7

Fajarta, C. R. (16 March 2017). RPTRA Sungai Bambu Jadi Pusat Kegiatan Pemberdayaan Ekonomi Warga. Beritasatu.

https://www.beritasatu.com/megapolitan/419758-rptra-sungai-bambu-jadi-pusatkegiatan-pemberdayaan-ekonomi-warga.html.

Fitrianny, R. (3 November 2017). Sentuhan Boleh Sentuhan Tidak Boleh. Kompasiana. https://www.kompasiana.com/deardarrell/59fc344ec226f9101c20d023/sentuhan -boleh-sentuhan-tidak-boleh

Geldard, K., \& Geldard, D. (2008). Counselling children: A practical introduction. In Counselling Children: A Practical Introduction. SAGE Publication: UK. 
Gibson, K., \& Cartwright, C. (2014). Young people's experiences of mobile phone text counselling: Balancing connection and control. Children and Youth Services Review, 43, 96-104.

\section{https://doi.org/10.1016/j.childyouth.2014.05.010}

Holzner, B. M., \& Oetomo, D. (2004). Youth, sexuality and sex education messages in Indonesia: Issues of desire and control. Reproductive Health Matters, 12, 40-49.

https://doi.org/10.1016/S0968-8080(04)23122-6

Hong, J. S., \& Espelage, D. L. (2012). A review of research on bullying and peer victimization in school: An ecological system analysis. Aggression and Violent Behavior, 17, 311-322.

https://doi.org/10.1016/j.avb.2012.03.003

Hurlock, E. B. (1967). Adolescent Development. Canadian Journal of Counselling and Psychotherapy, 5(4)

Kemenkes R. I. (2013). Buku pegangan sosialisasi JKN. Climate Change 2013 - The Physical Science Basis.

https://doi.org/10.1017/CB09781107415324.004

Kholisoh, N. (2018). Media literacy training for senior high school students in administrative village of Rawa Buaya in addressing pornographic content on youtube social media. ICCD, 1, 200-205.

https://doi.org/10.33068/iccd.vol1.iss1.31

KPAI. (2019, 8 January). Sepanjang 2018, KPAI Terima 4.885 Kasus Pelanggaran Hak Anak. Kompas.

https://nasional.kompas.com/read/2019/01/08/18472551/sepanjang-2018-kpaiterima-4885-kasus-pelanggaran-hak-anak

KPAI. (2019, May 2). Angka Kekerasan pada Anak Januari-April 2019 Masih Tinggi. Detik News.

https://news.detik.com/berita/d-4532984/kpai-angka-kekerasan-pada-anakjanuari-april-2019-masih-tinggi

KPAI. (2020, February 10). Sejumlah Kasus Bullying Sudah Warnai Catatan Masalah Anak di Awal 2020, Begini Kata Komisioner KPAI. Komisi Perlindungan Anak Indonesia. https://www.kpai.go.id/berita/sejumlah-kasus-bullying-sudah-warnai-catatanmasalah-anak-di-awal-2020-begini-kata-komisioner-kpai 
Suraya Mansur | ASEAN Journal of Community Engagement | Volume 4, Number 1, 2020

Laurensius, S., Situngkir, D., Putri, R., \& Fauzi, R. (2019). Cyber Bullying Against Children in Indonesia. In International Conference on Social Sciences, Humanities, Economics and Law. European Alliance for Innovation (EAI).

https://doi.org/10.4108/eai.5-9-2018.2281372

Limawan, A., Wiguna, T., Ismail, R. I., \& Sekartini, R. (2016). 2.55 The association between age, gender, and bullying experience among secondary high school students in Jakarta, Indonesia. Journal of the American Academy of Child \& Adolescent Psychiatry, 55.

https://doi.org/10.1016/j.jaac.2016.09.121

Maradewa, R. (2019, May 4). KPAI: 67 Persen Kekerasan Bidang Pendidikan Terjadi di Jenjang SD. Retrieved from

https://www.kpai.go.id/berita/kpai-67-persen-kekerasan-bidang-pendidikanterjadi-di-jenjang-sd

Milles, M. B., Huberman, M. A., \& Saldana, J. (2014). Qualitative Data Analysis A methods Sourcebook, Third Edition. Sage Publications, Inc.

Morrison, S. E., Bruce, C., \& Wilson, S. (2018). Children's disclosure of sexual abuse: A systematic review of qualitative research exploring barriers and facilitators. Journal of Child Sexual Abuse, 27(2), 176-194.

https://doi.org/10.1080/10538712.2018.1425943

Nielsen, L. (2002). The simulation of emotion experience: On the emotional foundations of theory of mind. Phenomenology and the Cognitive Sciences, 1, 255-286.

https://doi.org/10.1023/A:1021359916894

Norris, P. (2015). Sexual assault. In Emergency Medical Services: Clinical Practice and Systems Oversight, Second Edition.

https://doi.org/10.1002/9781118990810.ch61

Parke, R. D., Leidy, M. S., Schofield, T. J., Miller, M. A., \& Morris, K. L. (2008). Socialization. In Encyclopedia of Infant and Early Childhood Development. https://doi.org/10.1016/B978-012370877-9.00152-3

Parsons, T., Bales, R. F., Olds, J., Zelditch, M., \& Slater, P. E. (2014). Family: Socialization and interaction process. In Family: Socialization and Interaction Process. 
Powell, P., Sorefan, Z., Hamilton, S., Kneebone, R., \& Bello, F. (2016). Exploring the potential of sequential simulation. Clinical Teacher, 13, 112-118.

https://doi.org/10.1111/tct.12391

Rostanti, Q. (2015, December 30). KPAI: Kasus Bullying di Sekolah Meningkat Selama 2015. Republika.

https://nasional.republika.co.id/berita/nasional/umum/15/12/30/o067zt280-

kpai-kasus-bullying-di-sekolah-meningkat-selama-2015

Rice, R. E., \& Atkin, C. K. (2017). Public Communication Campaigns. In Public Communication Campaigns.

https://doi.org/10.4135/9781544308449

Self-Brown, S., Rheingold, A. A., Campbell, C., \& De Arellano, M. A. (2008). A media campaign prevention program for child sexual abuse: Community members' perspectives. Journal of Interpersonal Violence, 23, 728-743.

https://doi.org/10.1177/0886260507313946

Setiawan, S., Saifunuha, M. A., Kautsar, J. L., \& Wulandari, C. (2019). Community empowerment on establishment of friendly-village for women and children. Indonesian Journal of Advocacy and Legal Services, 1, 5-22.

https://doi.org/10.15294/ijals.v1i1.33756

Setyawan, D., \& KPAI. (2017, September 17). Tahun 2017, KPAI Temukan 116 Kasus Kekerasan Seksual Terhadap Anak. Komisi Perlindungan Anak Indonesia.

https://www.kpai.go.id/berita/tahun-2017-kpai-temukan-116-kasus-kekerasanseksual-terhadap-anak

Setyawan, D. (2018, March 20). KPAI: Kekerasan Seksual Anak Laki-Laki Meningkat. Komisi Perlindungan Anak Indonesia.

https://www.kpai.go.id/berita/kpai-kekerasan-seksual-anak-laki-laki-meningkat

Shanton, K., \& Goldman, A. (2010). Simulation theory. Wiley Interdisciplinary Reviews: Cognitive Science, 1, 527-538.

https://doi.org/10.1002/wcs.33

Simanjuntak, T. P. M., Hari, P. (2016, June 1). 100 orang Kunjungi RPTRA Sungai Bambu. Berita Jakarta.

http://www.beritajakarta.id/read/31630/per-hari-100-orang-kunjungi-rptrasungai-bambu\#.XzCUpRMzYbk 
Suraya Mansur | ASEAN Journal of Community Engagement | Volume 4, Number 1, 2020

Sori, C. F., \& Hecker, L. L. (2015). Ethical and legal considerations when counselling children and families. Australian and New Zealand Journal of Family Therapy, 36, 450464.

https://doi.org/10.1002/anzf.1126

Supriadi, D., \& Sa'ud, U. S. (2017). The effectiveness of implementing information and communication technology on student academic services (a case study in Bandung Institute of Technology for the 2015-2016 period). International Journal of Education, 9.

\section{https://doi.org/10.17509/ije.v9i2.5478}

Suraya, S., Manggiasih, P (2019). Public relations campaign "Forever against animal testing" by the body shop. International Journal of Humanities and Social Science Research, 5(3), 39-44.

http://www.socialsciencejournal.in/archives/2019/vol5/issue3/5-3-16

Tsuda, S., Scott, D., Doyle, J., \& Jones, D. B. (2009). Surgical skills training and simulation. Current Problems in Surgery, 46, 271-370.

https://doi.org/10.1067/j.cpsurg.2008.12.003

Tsuda, S., Hartini, S., Hapsari, E. D., \& Takada, S. (2017). Sex education in children and adolescents with disabilities in Yogyakarta, Indonesia from a teachers' gender perspective. Asia-Pacific Journal of Public Health, 29, 328-338.

https://doi.org/10.1177/1010539517702716

Vangelisti, A. L. (2004). Handbook of Family Communication. The Routledge:Taylor and Francis.

https://doi.org/10.5860/choice.41-4963

Villaluz, G. D. (2017). People empowerment: An approach towards indigenous early childhood curriculum. ASEAN Journal of Community Engagement, 1(1) 96-107. https://doi.org/10.7454/ajce.v1i1.64

Wang, X., Yu, C., \& Wei, Y. (2012). Social media peer communication and impacts on purchase intentions: A consumer socialization framework. Journal of Interactive Marketing, 26, 198-208. 
Widiastuti, R. (2018, July 28). Hari Anak Nasional, KPAI Catat Kasus Bullying Paling Banyak. Tempo.

https://nasional.tempo.co/read/1109584/hari-anak-nasional-kpai-catat-kasusbullying-paling-banyak

Zhang, W., Chen, J., Feng, Y., Li, J., Liu, C., \& Zhao, X. (2014). Evaluation of a sexual abuse prevention education for Chinese preschoolers. Research on Social Work Practice, 24, 428-436.

https://doi.org/10.1177/1049731513510409 